\title{
Vida Saludable para Personas de Edad: ¡Use Sus Medicinas Con Prudencia! ${ }^{1}$
}

\section{Paulina Wittkowsky}

Las medicinas nos ayudan a sentirnos mejor. Pero también

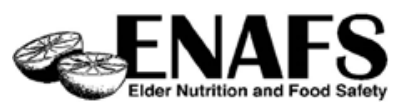
pueden hacernos daño si no las usamos correctamente. Para usar sus medicinas con prudencia, tenga en mente los siguientes consejos.

\section{Informe a su médico y a su farmacéutico sobre todas las medicinas que está tomando.}

Esto incluye medicinas recetadas por su médico, medicinas despachadas sin receta, hierbas y suplementos vitamínicos. Además, hágales saber si usted es alérgico o ha tenido una reacción a alguna droga.

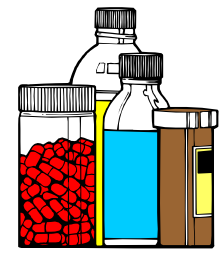

\section{Compre todas las medicinas que le receta su médico en la misma farmacia.}

De esta forma, todas las medicinas recetadas por su médico aparecen en su historial. Su farmacéutico podrá alertarle a usted y a su médico sobre posibles problemas. Avísele a su farmacéutico si su médico le ha dicho que no necesita seguir tomando alguna de sus medicinas, para que lo incluya en su historial.

\section{Asegúrese de poder leer la etiqueta de la medicina y de entender las indicaciones.}

Si le es difícil leer la etiqueta de la medicina que le han recetado, pídale al farmacéutico que la imprima con letras grandes. También debe leer las indicaciones de las medicinas que se despachan sin receta.

\section{Lleve un registro de todas las medicinas que está tomando.}

Guarde una copia en su casa y lleve una copia siempre con usted. Anote:

- el nombre de la medicina

- para qué la toma

- a qué horas debe tomarla

- cuánto debe tomar

- hasta cuándo debe tomarla

- si tiene efectos

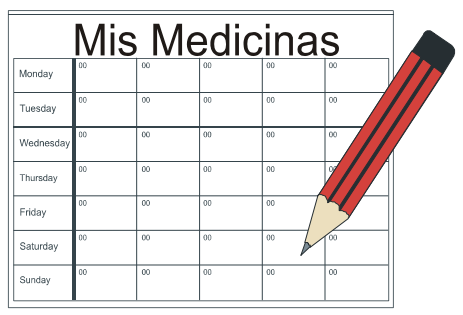
secundarios (como somnolencia o estreñimiento)

\footnotetext{
1. This document, FCS8594-Span, is one in a series of the Department of Family, Youth and Community Sciences, Institute of Food and Agricultural Sciences, University of Florida, Gainesville, FL 32611. Publication date: March 2004. This leaflet was developed with funding from the Florida Department of Elder Affairs in partnership with state, county, and local agencies. Please visit the EDIS Web site at http://edis.ifas.ufl.edu

2. Paulina Wittkowsky, MS, RD, former education assistant, Department of Family, Youth and Community Sciences, University of Florida, Gainesville, FL 32611. Reviewed by Linda B. Bobroff, PhD, RD, LD/N, professor and Isabel Valentin-Oquendo, MS, RD, former FNP curriculum coordinator, University of Florida.
} 


\section{Llame a su médico de inmediato si tiene algún problema con sus medicinas.}

Si usted siente que su medicina le está dando problemas en vez de alivio, háblele a su médico. Es probable que él o ella pueda recetarle una medicina diferente.

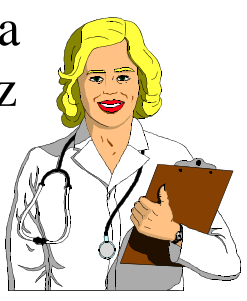

\section{Revise la fecha de vencimiento de sus medicinas.}

Tírelas a la basura si están vencidas. Pregúntele a su médico si necesita una nueva receta.

\section{Pregúntele a su médico o} farmacéutico si debe o no debe tomar las medicinas con los alimentos.

Algunos alimentos y bebidas deben evitarse si usted toma ciertas medicinas. A veces es mejor tomar la medicina conjuntamente con los alimentos para prevenir la irritación del estómago.

No tome más ni menos de la cantidad de medicina que le han recetado.

Su médico sabe cuál es la

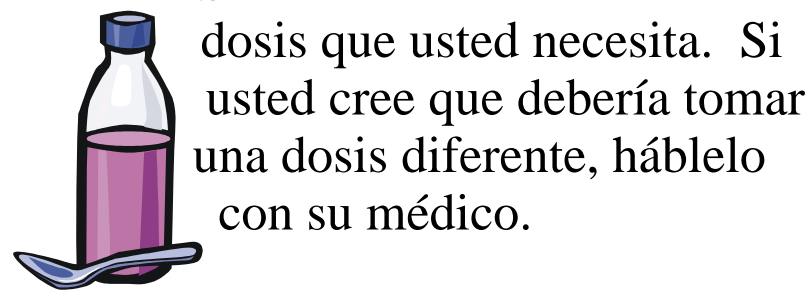

\section{No beba alcohol cuando toma sus medicinas.}

Algunas drogas no son eficaces o pueden enfermarle si se toman con alcohol. Pregúntele a su médico si el alcohol puede afectar las medicinas que usted está tomando.

\section{Nunca tome remedios que han sido recetados a otra persona.}

Los remedios que receta un médico no deben ser compartidos. Estos pueden aliviar a una persona pero ser dañinos para otra persona.

Si usted tiene dudas sobre sus medicinas, ¡háblele a su médico o a su farmacéutico! Usted debe tener información sobre su salud y sus medicinas, $y$ debe poder comprenderla.

\section{Para saber más sobre cómo usar las medicinas con prudencia:}

- Llame a la Administración de Drogas y Alimentos libre de cargo al 1-888INFOFDA (1-888-463-6332), o visite su sitio de web: www.fda.gov

- Llame al Servicio de Farmacia de la AARP libre de cargo al 1-800-4562277 o visite su sitio de web: www.aarppharmacy.com

- Visite el sitio de web de la Asociación Farmacéutica Americana: www.pharmacyandyou.org 